\title{
The Influence of Green Transformational Leadership and Motivation to Sustainable Corporate Performance with Organizational Citizenship Behavior for the Environment as a Mediating: Case Study at PT Karya Mandiri Sukses Sentosa
}

\author{
Dymas Widisatria and Lenny Christina Nawangsari
}

\section{ABSTRACT}

\begin{abstract}
This research was conducted aiming to reveal how much the influence of Green Transformational Leadership and Motivation on Sustainable Corporate Performance with Organizational Citizenship Behavior for The Environment (OCBE) as a mediating variable. The method of data collection in this research used a questionnaire method by taking a saturated sample of 40 employees at PT Karya Mandiri Sukses Sentosa. Data analysis used descriptive statistics using SPSS and analysis method of Structural Equation Modeling (SEM) with variance-based multivariate statistical techniques using PLS. The results showed that: 1) There was a positive and significant influence on green transformational leadership on sustainable corporate performance, 2) There was a positive and significant influence motivation on sustainable corporate performance, 3 ) There was a positive and significant influence OCBE on sustainable corporate performance, 4) There was a positive and significant influence on Green Transformational leadership towards OCBE, 5) There was a positive and significant influence motivation on OCBE, 6) OCBE mediates the influence of green transformational leadership on sustainable corporate performance, 7) OCBE mediates the influence of motivation on sustainable corporate performance.
\end{abstract}

Keywords: Green Transformational Leadership, Motivation, Sustainable Corporate Performance, Organizational Citizenship Behavior for The Environment (OCBE).

\section{INTRODUCTION}

Human resources are very important organizational assets for the company. This is because no matter how advanced the technology is used, or how much money is prepared, it will not be meaningful without professional human resources. In order to achieve goals, every organization requires management related to efforts to utilize organizational resources effectively and efficiently. Effectiveness means that it can achieve goals according to planning, and efficiently means that existing tasks are carried out correctly, organized and in accordance with predetermined targets [1].

In the era of globalization, which is full of challenges and competition, employees are an important element in a company that always plays an active role in determining the success of the company. Including human resources at PT Karya Mandiri Sukses Sentosa. PT Karya Mandiri Sukses Sentosa is a digital printing distributor company in Jakarta. PT Karya Mandiri Sukses Sentosa itself is a private company that has a small number of employees. In addition, the resulting turnover is around hundreds of trillions so that PT Karya Mandiri Sukses Sentosa has the opportunity to run a sustainable business. According to Mulhadi [2], small
Submitted : May 04, 2021

Published : May 25, 2021

ISSN: 2507-1076

DOI: $10.24018 /$ ejbmr.2021.6.3.876

Dymas Widisatria

Master of Management, Mercu Buana University, Jakarta, Indonesia.

(e-mail: dymaswidisatria07@gmail.com)

Lenny Christina Nawangsari

Master of Management, Mercu Buana University, Jakarta, Indonesia.

* Corresponding Author companies play an important role in the private company community. Experience in several developed countries (America, England, Japan).

The demands in this era of globalization are all companies are required to do a sustainable business which includes considering three dimensions of sustainability such as economy (energy and resource conservation), environment (minimizing negative impacts and waste) and social (providing equal opportunities for everyone regarding environmental conservation). Nawangsari and Sutawidjaya revealed that in this era of globalization, companies face challenges related to business sustainability [3]. Companies are required to have a role in protecting the environment and improving environmental-based human resource management strategies to maintain their existence in the business world. Sustainable Corporate is considered as an important part of sustainable development to achieve global sustainability.

Based on research, John put forward a major breakthrough which is well known, namely "The Triple Bottom Line" or called 3P (Profit, People, Planet) [4]. The concept recognizes that companies must pay attention to the 3Ps in maintaining the 'life' of their business. Not only concerned with profit but 
also having to make a positive contribution to society and actively participate in preserving the environment. The first $P$ is profit. Profit at the PT KMSS company has decreased in achieving its annual profit target as seen from the Percentage of Profit Achievement which can be seen in Fig. 1.

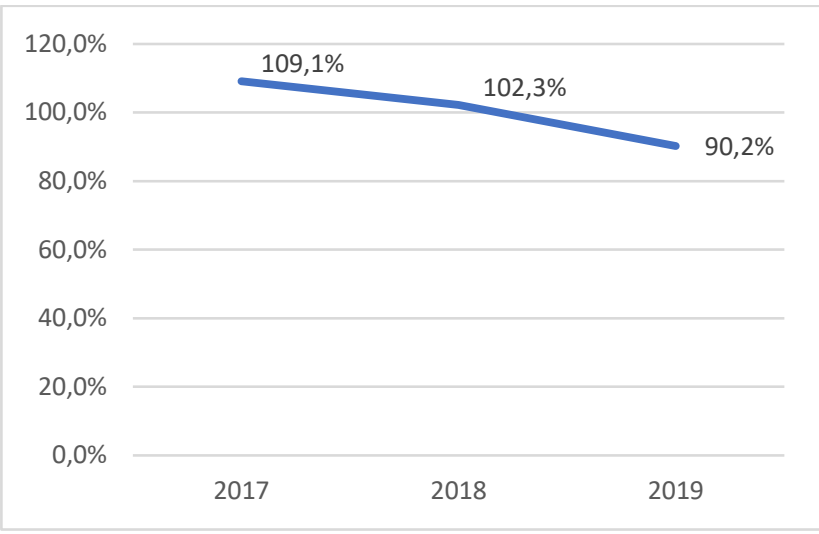

Fig. 1. PT KMSS Profit Target Achievement Chart (2017-2019).

Based on Fig. 1 shows that every year there is a decrease in the achievement of profits every year so that the target of the company has increased but cannot reach the target set by the company.

People is a community environment (community) where the company is located both employees and the surrounding community. In the people aspect, PT KMSS has made employees prosperous by providing allowances, besides that, every floor is equipped with first aid kits to maintain safety and health at work. In the community, PT KMSS distributes compensation and basic foodstuffs to orphans and underprivileged people around the company.

Planet refers to the physical environment associated with the company, for example the environment where the company is founded and the environment in which the company gets raw materials and resources. On the planetary aspect, PT KMSS has made efforts to reduce the use of paper so that in making reports using soft files, thus reducing paper waste when running company operations. In addition, in practice, product shipments are carried out simultaneously so as to increase effectiveness in shipping goods and reduce the number of vehicles used in shipping which have an impact on reducing carbon emissions in the air.

According to a survey through an interview with the Chief Executive Officer (CEO) of PT KMSS, the problem with sustainable company performance is still not optimal. This is influenced by the initiative and motivation of employees because PT KMSS is a digital printing distributor company so that they work more statically so that there are still many employees. who feel too comfortable so that motivation to work decreases. Based on the results of the pre-survey conducted on 18 respondents at PT KMSS, it shows that the company is still not optimal. Whereas at the same time it shows that the performance of sustainable companies has decreased, influenced by green transformational leadership that has not been maximal in becoming a green role model for employees. besides that, it can be seen that there are still many employees who are motivated to work just to get compensation. In addition, the results show that the Organizational Citizenship Behavior for Environment in PT KMSS is still very low. So, based on the background of the problem above, the authors are interested in further researching about Green Transformational Leadership and Motivation which affects Sustainable Corporate Performance with Organizational Citizenship Behavior for Environment as a mediating.

\section{LITERATURE REVIEW AND HYPOTHESIS DEVELOPMENT}

\section{A. Influence Green Transformational Leadership towards Sustainable Corporate Performance}

The performance of employees and companies that are sustainable requires environment-specific transformational leadership [5]. Green transformational leadership is an important element in improving the green performance of a company [17]. In addition, it is written in Wang et al. [6] green transformational leadership is positively related to the appropriateness of employees 'perceptual values and has a significant effect on employees' environmentally friendly behavior. Based on the description above, the hypothesis can be formulated:

H1: Green Transformational Leadership has a positive and significant effect on Sustainable Corporate Performance.

\section{B. Influence Green Transformational Leadership towards Organizational Citizenship Behavior for Environment (OCBE)}

Transformational leadership effectively promotes OCBE, but the transformational leadership dimensions have different pathways and strengths in influencing OCBE [7]. Transformational leaders are able to influence followers to do something more than expected [8]. Based on the description above, the following hypothesis can be formulated:

H2: Green Transformational Leadership has a positive and significant effect on OCBE.

\section{Influence of Motivation on Organizational Citizenship} Behavior for Environment (OCBE)

Work motivation has a significant effect on OCBE [9]. This is in line with the results of previous research by Laura M. Graves, Joseph Sarkis, Qinghua Zhu [10] which showed that employee work motivation is very important and influences the behavior of OCBE employees. Another study, namely Deci and Ryan [11] stated that autonomous motivation has a stronger influence on increasing behavior persistence, welfare, psychological health, and pro environmental behavior. Autonomous motivation is also associated with increased employee awareness of the environment and pro-environmental behavior [12]. Based on the description above, the following hypothesis can be formulated:

H3: Motivation has a positive and significant effect on OCBE.

\section{Influence Organizational Citizenship Behavior for Environment $(\mathrm{OCBE})$ on Sustainable Corporate Performance}

Organizational Citizenship Behavior for Environment relevant is the participation of environmentally friendly employees. Providing Eco-Initiatives, Eco-Civic Engagement, and Eco-Helping through employee engagement inspires employees to engage and initiate new 
thinking about ecological practices, help them adopt the organization's environmental priorities, and create effective environmental management systems for sustainable performance [13] . OCBE is a wise action by employees in an organization that leads to environmental improvement without any appreciation or request from the organization [18]. Therefore, employees are more interested in volunteering in environmental programs, if they are allowed to make decisions and recommendations about environmental issues [4]

Based on the description above, the following hypothesis can be formulated:

H4: Organizational Citizenship Behavior for The Environment (OCBE) has a positive and significant effect on Sustainable Corporate Performance.

H7: Green Transformational Leadership has a positive and significant effect on Sustainable Corporate Performance with OCBE as a mediator.

\section{E. Influence Motivation for Sustainable Corporate Performance}

Motivation is a condition that influences to generate, direct, and maintain behavior related to the work environment [14]. The relationship between motivation, work passion and optimal results has a linear form in the sense that by providing good work motivation, the employee's work passion will increase, and the work results will be optimal in accordance with the set performance standards. According to research by Brahmasari \& Suprayetno [15] the results of this study prove that work motivation has a significant positive effect on company performance. Based on the description above, the following hypothesis can be formulated:

H5: Motivation has a positive and significant effect on Sustainable Corporate Performance.

H6: Motivation has a positive and significant effect on Sustainable Corporate Performance with OCBE as a mediator.

\section{RESEARCH METHODOLOGY}

This study uses a quantitative approach because it is more concerned with measurement and sampling methods using a deductive approach that emphasizes detailed priorities in data collection and analysis. In this study, the sample used is a saturated sample, namely all employees, namely 40 samples of employees of PT Karya Mandiri Sukses Sentosa. The number of samples in the PLS-SEM does not require a large number of samples. The minimum recommended is between 30 and 100 cases [16]. Retrieval of data using a questionnaire, observation, and documentation. The data that has been collected will be analyzed using Structural Equation Modeling (SEM), which is one of the methods currently used to cover weaknesses in the regression method.

\section{RESEARCH RESULT AND DISCUSSION}

This study aims to determine the effect of green transformational leadership and motivation on sustainable corporate performance through organizational citizenship behavior for the environment (OCBE) among employees of PT Karya Mandiri Sukses Sentosa. In this study, data were obtained by distributing questionnaires to 40 respondents who were employees of PT Karya Mandiri Sukses Sentosa.

TABLE I: DESCRIPTIVE STATISTICS OF RESEARCH VARIABLES

\begin{tabular}{|c|c|c|}
\hline Variable & Indicator & Mean \\
\hline \multirow{10}{*}{$\begin{array}{c}\text { Green } \\
\text { Transformational } \\
\text { Leadership }\end{array}$} & $\mathrm{X} 1.1$ & 4.40 \\
\hline & $\mathrm{X} 1.2$ & 4.43 \\
\hline & $\mathrm{X} 1.3$ & 4.48 \\
\hline & X1.4 & 4.15 \\
\hline & $\mathrm{X} 1.5$ & 4.48 \\
\hline & X1.6 & 4.58 \\
\hline & $\mathrm{X} 1.7$ & 4.40 \\
\hline & $\mathrm{X} 1.8$ & 4.63 \\
\hline & X1.9 & 4.38 \\
\hline & $\mathrm{X} 1.10$ & 4.45 \\
\hline \multirow{10}{*}{ Motivation } & $\mathrm{X} 2.1$ & 3.95 \\
\hline & $\mathrm{X} 2.2$ & 4.05 \\
\hline & $\mathrm{X} 2.3$ & 4.15 \\
\hline & $\mathrm{X} 2.4$ & 3.68 \\
\hline & $\mathrm{X} 2.5$ & 4.10 \\
\hline & $\mathrm{X} 2.6$ & 4.00 \\
\hline & $\mathrm{X} 2.7$ & 3.45 \\
\hline & $\mathrm{X} 2.8$ & 3.93 \\
\hline & $\mathrm{X} 2.9$ & 4.33 \\
\hline & $\mathrm{X} 1.10$ & 3.85 \\
\hline \multirow{10}{*}{$\begin{array}{c}\text { Organizational } \\
\text { Citizenship for The } \\
\text { Environment }\end{array}$} & Y1.1 & 3.75 \\
\hline & Y1.2 & 3.60 \\
\hline & Y1.3 & 3.90 \\
\hline & Y1.4 & 3.83 \\
\hline & Y1.5 & 3.80 \\
\hline & Y1.6 & 3.80 \\
\hline & Y1.7 & 3.85 \\
\hline & Y1.8 & 3.83 \\
\hline & Y1.9 & 3.55 \\
\hline & Y1.10 & 3.58 \\
\hline \multirow{10}{*}{$\begin{array}{l}\text { Sustainable Corporate } \\
\text { Performance }\end{array}$} & Y2.1 & 4.20 \\
\hline & Y 2.2 & 4.20 \\
\hline & $\mathrm{Y} 2.3$ & 4.35 \\
\hline & Y 2.4 & 4.18 \\
\hline & $\mathrm{Y} 2.5$ & 4.30 \\
\hline & Y2.6 & 3.98 \\
\hline & Y2.7 & 4.33 \\
\hline & Y 2.8 & 4.30 \\
\hline & Y2.9 & 4.20 \\
\hline & Y 2.10 & 4.33 \\
\hline
\end{tabular}

Based on the results of the variable description, it shows that the green transformational leadership (X1) variable on the X1.8 indicator has the highest mean value of 4.63 or it can be interpreted that $92.6 \%$ of respondents agree that leaders at PT KMSS have good relationships with their employees. Meanwhile, the indicator with the lowest mean value is the environmental maintenance indicator with the green idealized influence dimension with a mean value of 4.15.

The motivation variable (X2) on the X2.9 indicator has the highest mean value of 4.33 or it can be interpreted that $86.6 \%$ of respondents agree that rewarding work results will increase motivation. Meanwhile, the indicator that has the lowest mean value is that the indicator has power in the group with the need of power dimension with a mean value of 3.45 or it can be interpreted that only $69 \%$ of respondents agree that they have power in the group. The variable organizational citizenship behavior for the environment (Y1) on the Y1.3 indicator has the highest mean value of 3.90 or it can be interpreted that $78 \%$ of respondents agree that it is efficient in using office equipment.

The sustainable corporate performance (Y2) variable on the Y2.3 indicator has the highest mean value of 4.35 or it can be interpreted that $87 \%$ of respondents agree that sales that 
occur at PT KMSS always increase. While the indicator that has the lowest mean value is the indicator of environmental culture application with environmentally sustainable dimensions with a mean value of 3.98 or it can be interpreted that only $79.6 \%$ of respondents agree that the implementation of organizational culture has been implemented at PT KMSS.

The results of hypothesis testing using SEM PLS using the structural model evaluation (inner model).

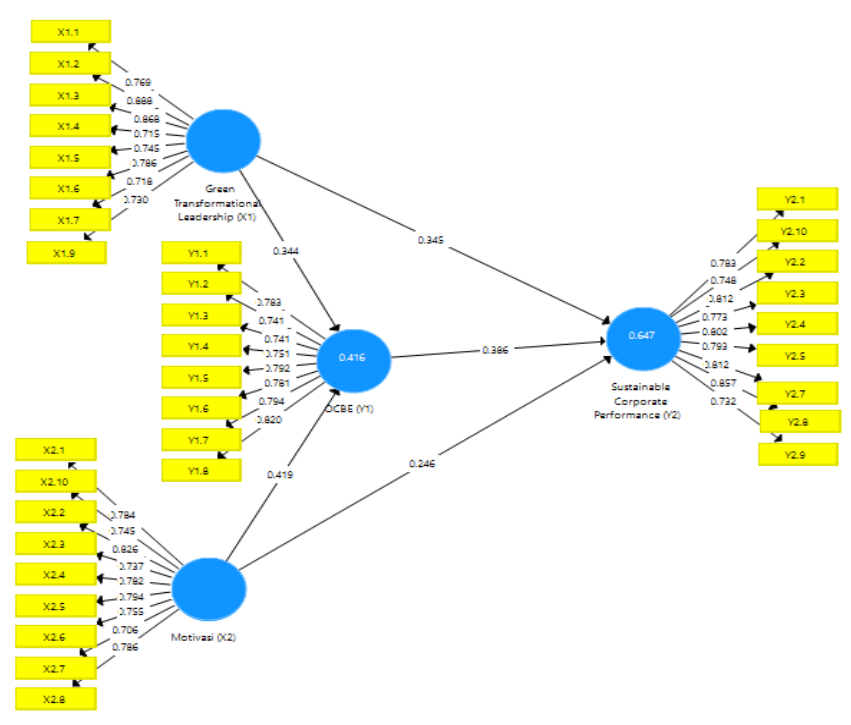

Fig. 2. Path Coefficient Value.

TABLEII: VALUE OF T-STATISTICS, AND P-VALUE

\begin{tabular}{|c|c|c|c|}
\hline Construct & $t$-statistics & p-value & Information \\
\hline \multicolumn{4}{|l|}{ Direct } \\
\hline $\begin{array}{l}\text { Green Transformational } \\
\text { Leadership -> OCBE }\end{array}$ & 2,781 & 0.008 & $\begin{array}{l}\text { Positive } \\
\text { Significant }\end{array}$ \\
\hline $\begin{array}{l}\text { Green Transformational } \\
\text { Leadership -> Sustainable } \\
\text { Corporate Performance }\end{array}$ & 2,771 & 0.004 & $\begin{array}{l}\text { Positive } \\
\text { Significant }\end{array}$ \\
\hline Motivation $->$ OCBE & 3,559 & 0.001 & Positive Significant \\
\hline $\begin{array}{l}\text { Motivation -> Sustainable } \\
\text { Corporate Performance }\end{array}$ & 2,080 & 0.041 & $\begin{array}{c}\text { Positive } \\
\text { Significant }\end{array}$ \\
\hline $\begin{array}{l}\text { OCBE -> Sustainable } \\
\text { Corporate Performance }\end{array}$ & 2,775 & 0.005 & $\begin{array}{c}\text { Positive } \\
\text { Significant }\end{array}$ \\
\hline
\end{tabular}

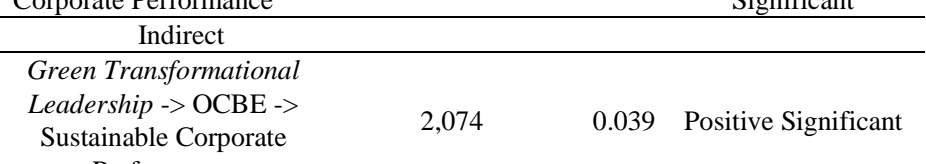
Performance

Motivation -> OCBE ->

Sustainable Corporate $\quad 2,053 \quad 0.046$ Positive Significant Performance

\section{A. The Influence of Green Transformational Leadership on $O C B E$}

Green Transformational Leadership (X1) has a significant positive effect on OCBE (Y1). It is known that the value of $\mathrm{T}$-Value (2.781)> T table (2.030) then the hypothesis $\mathrm{H} 0$ is rejected and $\mathrm{H} 1$ is accepted. This means that there is a significant positive effect of Green Transformational Leadership (X1) on OCBE (Y1). The coefficient value of Green Transformational Leadership (X1) to OCBE (Y1) is 0.344 . The coefficient value shows a direct effect, that is, if the other variables are constant, then OCBE (Y1) is influenced by $34.4 \%$ by Green Transformational Leadership (X1). This explains that the better the Green Transformational Leadership (X1), the OCBE (Y1) will be better or increase. Likewise, if the Green Transformational Leadership (X1) is lower, the OCBE (Y1) will be lower or decrease.

According to $\mathrm{Mi}$ et al. [7], transformational leadership effectively promotes OCBE, but the transformational leadership dimensions have different paths and strengths in influencing OCBE. Transformational leaders are able to influence followers to do something more than expected [8]. Research conducted by Lestari [19], namely the effect of green transformational leadership, organizational commitment, and autonomous motivation on organizational citizenship behavior for the environment states that green transformational leadership has a significant effect on organizational citizenship behavior for the environment.

\section{B. The Influence of Green Transformational Leadership on Sustainable Corporate Performance}

Green Transformational Leadership (X1) has a significant positive effect on Sustainable Corporate Performance (Y2). It is also known that the value of $\mathrm{T}$-Value $(2.771)>\mathrm{T}$ table (2.030) means that the hypothesis $\mathrm{H} 0$ is rejected and $\mathrm{H} 1$ is accepted. This means that there is a significant positive effect of Green Transformational Leadership (X1) on Sustainable Corporate Performance (Y2). The coefficient value of Green Transformational Leadership (X1) on Sustainable Corporate Performance (Y2) is 0.345 . The coefficient value shows a direct effect, that is, if the other variables are constant, the Sustainable Corporate Performance (Y2) is influenced by $34.5 \%$ by Green Transformational Leadership (X1). This explains that the higher the value of Green Transformational Leadership (X1), the higher or increasing Sustainable Corporate Performance (Y2).

According to Jiang et al. [5], in creating sustainable employee and company performance requires environmentspecific transformational leadership [5]. In addition, green transformational leadership is positively related to the appropriateness of employees 'perceptual values and significantly influences employees' environmentally friendly behavior [6]. Employees who are inspired and intellectually stimulated by transformational leaders who are specific to the environment will be more likely to show concern for the environment, which in turn will have a positive impact on influencing employees to engage in green behavior in the workplace.

\section{The Influence of Motivation on $O C B E$}

Motivation (X2) has a significant positive effect on OCBE (Y1). It is also known that the value of T-Value (3.559)> T table (2.030) means that the hypothesis $\mathrm{H} 0$ is rejected and $\mathrm{H} 1$ is accepted. This means that there is a significant positive influence on Motivation (X2) on OCBE (Y1). The value of the Motivation coefficient (X2) on OCBE (Y1) is 0.419. The coefficient value shows a direct effect, that is, if the other variables are constant, then OCBE (Y1) is influenced by $41.9 \%$ by Motivation (X2). This explains that the higher the value of Motivation (X2), the OCBE (Y1) will be higher or increase. Likewise, if the value of Motivation (X2) is lower, the OCBE (Y1) will be lower or decrease.

According to Deci and Ryan [11], motivation has a stronger influence on increasing behavior persistence, welfare, psychological health, and pro environmental behavior. Motivation is also associated with increased employee awareness of the environment and proenvironmental behavior [20]. Work motivation can 
encourage employees to produce their best performance, which will create a feeling of pleasure in the employees in doing their work and will create a sense of initiative from within to do additional work that is not a formal task of the company [21].

\section{The Influence of Motivation on Sustainable Corporate Performance}

Motivation (X2) has a significant positive effect on Sustainable Corporate Performance (Y2). It is also known that the value of $\mathrm{T}$-Value (2.080)> T table (2.030) then the hypothesis $\mathrm{H} 0$ is rejected and $\mathrm{H} 1$ is accepted. This means that there is a significant positive influence on Motivation (X2) on Sustainable Corporate Performance (Y2). The value of the Motivation coefficient (X2) on Sustainable Corporate Performance (Y2) is 0.246. The coefficient value shows a direct effect, that is, if the other variables are constant then Sustainable Corporate Performance (Y2) is influenced by $24.6 \%$ by Motivation (X2). This explains that the higher the value of Motivation (X2), the higher or increasing Sustainable Corporate Performance (Y2). Likewise, if the value of Motivation (X2) is getting lower, then Sustainable Corporate Performance (Y2) will be lower or decrease.

The relationship between motivation, work passion and optimal results has a linear form in the sense that by providing good work motivation, the employee's work passion will increase, and the work results will be optimal in accordance with the set performance standards. According to research by Brahmasari \& Suprayetno [15] the results of this study prove that work motivation has a significant positive effect on sustainable company performance.

\section{E. The influence of OCBE on Sustainable Corporate Performance}

OCBE (Y1) has a significant positive effect on Sustainable Corporate Performance (Y2). It is also known that the value of T-Value (2.775)> T table (2.030) means that the hypothesis $\mathrm{H} 0$ is rejected and $\mathrm{H} 1$ is accepted. This means that there is a significant positive effect of OCBE (Y1) on Sustainable Corporate Performance (Y2). The value of the OCBE coefficient (Y1) on Sustainable Corporate Performance (Y2) is 0.386 . The coefficient value shows a direct effect, that is, if the other variables are constant, the Sustainable Corporate Performance (Y2) is influenced by $38.6 \%$ by OCBE (Y1). This explains that the higher the OCBE value (Y1), the Sustainable Corporate Performance (Y2) will be higher or increase. Likewise, if the OCBE (Y1) value gets lower, the Sustainable Corporate Performance (Y2) will be lower or decrease.

Organizational Citizenship Behavior for The Environment relevant is the participation of environmentally friendly employees. Providing Eco-Initiatives, Eco-Civic Engagement, and Eco-Helping through employee engagement inspires employees to engage and initiate new thinking about ecological practices, help them adopt the organization's environmental priorities, and create effective environmental management systems for sustainable performance [13]. Therefore, employees are more interested in volunteering in environmental programs, if they are allowed to make decisions and recommendations about environmental issues [4].
F. Green Transformational Leadership has a Significant Effect on Sustainable Corporate Performance with OCBE Mediation

Green Transformational Leadership has an influence on Sustainable Corporate Performance through OCBE. In accordance with the results of data processing, the path coefficient is 0.133 with a t-value of 2.074 which is greater than the t-table of 2.030 with a p-value of 0.039 , thus $\mathrm{H} 1$ is supported $(\mathrm{P}<0.05$ and $\mathrm{t}$-value $>\mathrm{t}$-table). The coefficient value of the influence of the Green Transformational Leadership (X1) variable on Sustainable Corporate Performance (Y2) through OCBE (Y1) is 0.133 which indicates that the greater the Green Transformational Leadership (X1), the more Sustainable Corporate Performance (Y2) through OCBE (Y1) will be big. The coefficient value shows an indirect effect, namely if the Green Transformational Leadership (X1) and OCBE (Y1) variables are constant, then Sustainable Corporate Performance (Y2) is affected by $13.3 \%$ by Green Transformational Leadership (X1). It can be concluded that Green Transformational Leadership has a significant effect on Sustainable Corporate Performance through OCBE.

OCBE is developed from the OCB (Organizational Citizenship Behavior) framework that occurs in the workplace and is an important aspect of corporate sustainability. Lamm et al. [22] define OCBE as voluntary behavior not specified in a formal job description, through the combined efforts of individual employees with the aim of helping a more sustainable organization and / or society. [5] stated that transformational leadership emphasizes the importance of social exchange between leader and followers in the form of a psychological contract, thereby stimulating OCBE.

\section{G. Motivation Has no Significant Influence on Sustainable Corporate Performance with OCBE Mediation}

Motivation has an influence on Sustainable Corporate Performance through OCBE. In accordance with the results of data processing, a path coefficient of 0.162 was obtained with a t-value of 2.053 greater than the $t$-table of 2.030 with a p-value of 0.046 , thus supporting $\mathrm{H} 1$ ( $\mathrm{P}<0.05$ and $\mathrm{t}$-value $>$ $\mathrm{t}$-table). The coefficient value of the influence of the Motivation variable (X2) on Sustainable Corporate Performance (Y2) through OCBE (Y1) is 0.162 which indicates that the greater the motivation $(\mathrm{X} 2)$, the greater the Sustainable Corporate Performance (Y2) through OCBE (Y1). The coefficient value shows an indirect effect, namely if the Motivation (X2) and OCBE (Y1) variables are constant, then Sustainable Corporate Performance (Y2) is affected by $16.2 \%$ by Motivation (X2).

The continuous process of identifying, measuring, developing individual and team performance and aligning their performance with organizational goals so that company performance can be achieved properly. Motivation is considered to be closely related to performance because the higher the motivation, the more it encourages employees to produce their best performance so that the company's performance will be supported. OCBE is related to employee performance because the voluntary behavior shown by employees in the environment will be able to help improve company effectiveness and be able to influence aspects of 
sustainable company performance [23].

\section{CONCLUSION AND SUGgestion}

Based on the results of the research and discussion that has been described in the previous chapter, it can be concluded that the results of this study are:

1) Green Transformational Leadership has a positive and significant effect on Sustainable Corporate Performance at PT KMSS. This shows that pro-environmental transformational leadership will support sustainable company performance.

2) Green Transformational Leadership has a positive and significant effect on Organizational Citizenship Behavior for The Environment at PT KMSS. This suggests that proenvironmental transformational leadership will support employees' voluntary behavior in protecting the environment.

3) Motivation has a positive and significant effect on Sustainable Corporate Performance at PT KMSS. This shows that employee motivation to work will support sustainable company performance.

4) Motivation has a positive and significant effect on Organizational Citizenship Behavior for The Environment at PT KMSS. This shows that employee motivation will support employee voluntary behavior in protecting the environment.

5) Organizational Citizenship Behavior for The Environment has a positive and significant effect on Sustainable Corporate Performance at PT KMSS. This shows that employees' voluntary behavior in protecting the environment will support sustainable company performance.

6) Green Transformational Leadership has a positive and significant effect on Sustainable Corporate Performance through mediation of Organizational Citizenship Behavior for The Environment at PT KMSS.

7) Motivation has a positive and significant effect on Sustainable Corporate Performance through mediation of Organizational Citizenship Behavior for The Environment at PT KMSS.

The author feels there are still many weaknesses in this study. The limitation in this study is that the sample used is very limited, so that further research can use a wider sample and a wider research object. The data used in this study is cross-sectional data, namely data collected at a specified time. OCBE and Green Transformational Leadership may take a long time to intervene and change behavior, it is suggested that future research can use longitudinal data. For further research that is interested in the same topic, it is suggested to explore the influence of independent (independent) variables on sustainable company performance, and involve other variables such as: compensation, green human resource, employee green behavior, and organizational culture.

\section{REFERENCES}

[1] Montolalu, R. (2016). The Influence of Personality, Work Orientation, and Employee Placement on Employee Performance at the Culture and Tourism Office of North Sulawesi Province. EMBA Journal. Vol. 4, No. 1.

[2] Mulhadi, D. (2014). Company Law Forms of Business Entities in Indonesia. Field.

[3] Nawangsari, L., C., \& Sutawidjaya, A., H. (2018). How the Green Human Resources Management (GHRM) Process Can Be Adopted for
The Organization Business. Advances in Economics, Business and Management Research, Vol. 65 pp. 463-465.

[4] Pinzone, M., Guerci, M., Lettieri, E., \& Redman, T. (2016). Progressing in the change journey towards sustainability in healthcare: The role of "Green" HRM. Journal of Cleaner Production. Vol 122, 201-211.

[5] Jiang W, Zhao X, \& Ni J. (2017). The Impact of Transformational Leadership on Employee Sustainable Performance: The Mediating Role of Organizational Citizenship Behavior. Sustainability. Vol. 9 (9) pp. 1567.

[6] Wang, X, Zhou, K., \& Liu, W., (2018). Value Congruence: A Study of Green Transformational Leadership and Employee Green Behavior. Front. Psychol. Vol. 9 pp. 1946.

[7] Mi, L., Gan, X., Xu, T., Long, R., Qiao, L., \& Zhu, H., (2019). A New Perspective to Promote Organizational Citizenship Behavior for the Environment: The Role of Transformational Leadership. Journal of Cleaner Production, Vol. 239 pp. 118002.

[8] Mathew, M., \& Gupta, KS (2015). Transformational Leadership: Emotional Intelligence. SCMS Journal of Indian Management, Vol. 12 (2) pp. 75 .

[9] Prasetya R, \& Nawangsari L. (2019). The Influence of Leadership Style, Organizational Culture, and Work Motivation on Organizational Citizenship Behavior for Environment (OCBE) of the Directorate General of Fiscal Balance's Employees. International Journal of Innovative Science and Research Technology. Vol 4, Issue 12.

[10] Graves, LM, Sarkis, J., \& Zhu, Q. (2013). How Transformational Leadership and Employee Motivation Combine to Predict Employee Proenvironmental Behaviors in China. Journal of Environmental Psychology. Vol 35, 81-91.

[11] Edward, L. Deci, Anja H. Olafsen and Richard M. Ryan. (2017). SelfDetermination Theory in Work Organizations: The State of a Science. The Annual Review of Organizational Psychology and Organizational Behavior, 4: 19-43.

[12] Mahendra I, \& Surya I. (2017). The Influence of Organizational Climate, Work Motivation, and Organizational Justice on Organizational Citizenship Behavior (OCB). E-Journal of Management, Udayana University. Vol. 6, No. 9, pp 4569-4688.

[13] Paillé, P., \& Boiral, O. (2013). Pro-Environmental Behavior at Work: Construct Validity and Determinants. Journal of Environmental Psychology, Vol. 36 pp. 118-128.

[14] AA Anwar Prabu Mangkunegara. (2005). Human Resource Management Company.Bandung: PT Remaja Rosdakarya.

[15] Brahmasari I, \& Suprayetno A. (2008). The Influence of Work Motivation, Leadership and Organizational Culture on Employee Job Satisfaction and its Impact on Company Performance (Case study at PT. Pei Hai International Wiratama Indonesia). Journal of Management and EntrepreneurshiP. Vol 10, No. 2, pp 124-135.

[16] Ghozali, I. (2015). Multivariate Analysis Application with IBM SPSS 23 Program. Semarang: Diponegoro University Publishing Agency.

[17] Zafar, A., Nisar, Q., A., Shoukat, M., \& Ikram, M., (2017). Green Transformational Leadership and Green Performance: The mediating role of Green Mindfulness and Green Self-efficacy. International Journal of Management Excellence, Vol. 9 (2) pp. 1-15

[18] Daily BF, Bishop JW, Govindarajulu N. (2009). A Conceptual Model for Organizational Citizenship Behavior Directed Toward the Environment. Business \& Society. Vol. 48 pp. 243-256.

[19] R Lestari U, \& Nawangsari L. (2019). The Influence of Green Transformational Leadership, Organizational Commitment and Autonomous Motivation on Organizational Citizenship Behavior for the Environment (OCBE): Concept Approach. In: Proceedings of the National Seminar on Higher Education Quality Improvement. Bali: Tanjung Benoa. P. 17-23.

[20] Otik, Imelda. (2016). The Influence of Leadership Style and Work Motivation on Employee Performance at the Directorate General of Training and Productivity Development of the Ministry of Manpower and Transmigration, RI Thesis. Master of Management, Mercu Buana University. Jakarta.

[21] Gautama K., and Edalmen. (2020). The Influence of Work Motivation on Employee Performance with Organizational Citizenship Behavior as Mediation. Managerial and Entrepreneurship Journal. Volume II No. 3/2020.

[22] Lamm, E., Tosti-Kharas, J., \& Williams, E., G. (2013). Read this Article, but Don't Print tt: Organizational Citizenship Behavior Toward the Environment. Group \& Organization Management, Vol. 38 (2) pp. 163-197.

[23] Ramasamy, Adimuthu; Ishmael Inore, and Richard Sauna. (2017). "A Study on Implications of Implementing Green HRM in the Corporate Bodies with Special Reference to Developing Nations". Vol. 12, No. 9 , 2017. 